\title{
A New Approach for Identifying Potentially Effective Indigenous Plants Consumed by Chenchu Tribes and Their Nutritional Composition-India
}

\section{Sreenivasa Rao Jarapala1 ${ }^{*}$, Godha Shivudu' ${ }^{1}$ Korra Mangathya1, Anita Rathod ${ }^{1}$, Hrusikesh Panda², Pendli Kalyan Reddy ${ }^{3}$}

${ }^{1}$ Food Chemistry Division, ICMR-National Institute of Nutrition, Tarnaka, Hyderabad, India

${ }^{2}$ NICHE Division, ICMR-National Institute of Nutrition, Tarnaka, Hyderabad, India

${ }^{3}$ Tribal Research Institute, Masab Tank, Hyderabad, India

Email: *sreenu.nin@gmail.com

How to cite this paper: Jarapala, S.R., Shivudu, G., Mangathya, K., Rathod, A., Panda, H. and Reddy, P.K. (2021) A New Approach for Identifying Potentially Effective Indigenous Plants Consumed by Chenchu Tribes and Their Nutritional Composition-India. American Journal of Plant Sciences, 12, 1180-1196.

https://doi.org/10.4236/ajps.2021.128082

Received: May 7, 2021

Accepted: August 1, 2021

Published: August 4, 2021

Copyright $\odot 2021$ by author(s) and Scientific Research Publishing Inc. This work is licensed under the Creative Commons Attribution International License (CC BY 4.0).

http://creativecommons.org/licenses/by/4.0/

\begin{abstract}
Traditional knowledge of plants and their properties always has been transmitted from generation to generation through the natural path of everyday life. Food habits of the indigenous population across the globe are very abnormal when compared to that of civilized people. The forest related tribal scientific studies of edible wild plants are extremely constructive to know the nutritional values of the forest indigenous foods and help to eliminate the malnutrition problems in vulnerable group. The existing study was undertaken with an intention and documented 34 exceptional plant species belonging to 15 families with their medicinal values, taxonomical names and nutritional profile. Among the 34 indigenous plant foods, the frequently available and consumed plant foods by particularly vulnerable tribal group Chenchu tribes were selected for nutritional investigation including proximate composition, mineral and vitamin analysis. Results show that the nutritional values of the edible indigenous plant foods are prominent compared to frequently consumed foods available in market. The present study observed that the conventional and nutritional information on wild plant foods is on sharp decline. Unless efforts are made to educate the present generations about the importance of these foods, which may be lost in near future. These studies could contribute significantly to Government policies to improve food security and helps to progress health and nutritional status in marginally deprived tribal communities in India, and in the enhancement of wild vegetable status, whose potential as sources of nutrition is currently undervalued.
\end{abstract}




\section{Keywords}

Chenchu Tribes, Indigenous Foods, Malnutrition, Government Policies

\section{Introduction}

Micronutrient malnutrition (MNM) is widespread in the developed nations and more severe in emergent regions of the world. All the age groups are prone to it, primarily young children and women of reproductive age are vastly vulnerable sections. MNM has numerous shocking effects on human wellbeing, not all of which are clinically apparent. Even sensible levels of deficiency (which can be detected by biochemical or clinical measurements) can have severe unfavorable effects on human function. The primary key step to control the nutritional (vitamin and mineral) deficiencies is to fight over hunger and malnutrition problems in vulnerable people particularly tribal population. In this path wild plants are playing an important role and these plant foods are consumed by the primitive groups that are the main source of food and medicine for marginally surviving communities particularly for marginally vulnerable people. These plant foods possess rich nutrients and medicinal values. Primitive tribes rely on natural resources such as plants and forest produce in addition to agriculture and animal items for their survival.

The estimated indigenous population living on globe is 370 million [1]. Indigenous peoples internationally suffer greater early mortality rates and poorer health status when compared with non-Indigenous peoples. Indigenous people's food systems are inextricably associated to land, which in turn is interwoven with issues of self-determination, livelihoods, health, cultural and spiritual heritage and gender. Similar to that of aboriginal populations globally, deficiency of India's Indigenous peoples has contributed to widespread difficulties and poor nutrition [2]. This is connected with the alter of nutritional patterns that occurred from utilization of conventional nutrient dense, low energy foods to a confidence in poorer value food handouts of staples such as rice. Because the food intake for Indigenous peoples has been further compounded by many factors [3] including insufficient food access and availability [4], food insecurity [5] and financial stress [6], the last identified as a substantial barrier to a healthy diet [7]. It is approved that superior quality health data from Indigenous populations internationally are limited [3] and this is also realistic for India's Indigenous people. Worldwide and countrywide there are few studies expansively tentative their food and nutrient intake [8]. This represents a serious gap in the information bottom mandatory to expand efficient health executive strategies for this at-risk population. In this regard, majority of the tribal population continue to suffer from acute malnutrition as a result of a global lack of adequate nutrition food.

Tribal population in India is superior to that of any other country in the world 
[9]. The tribes constitute more than nine percent of the country's total population which ranks second in world tribal population after African continent [9]. There are 450 tribes sub divided into 475 groups, spread over the length and breadth of country and concentrated mostly in the hills and forest regions. These tribes are initially residing in the planes and river valleys, but after the invasions of Aryans, had retreated to hilly forested and mountains area for their own security. In 1975 the Government of India identify the most vulnerable tribal groups, as a separate category naming it as particularly vulnerable tribal groups (PVTG) and the more vulnerable clusters among the tribal groups [10] [11] [12]. Among the 75 primitive tribal groups, the Chenchus are legitimately designated groups of historically deprived tribes in India who live in the hills of southern India, mostly in the states of Andhra Pradesh (AP) and Telangana (TS). The higher ranges of Nalamala forest and the Amrabad Plateau in combined AP are pure, dense forests and are almost exclusively occupied by the Chenchu tribes. Chenchu tribes still going for hunting instead of farming and other activities. Chenchu tribes are a conventional tribal crowd and have not made many changes in their lifestyle or tried to adapt to modernism. They live in the enclosed space and geography, leading a life of an unscathed continuity. Chenchu tribes collect forest plant foods and products including green leafy vegetables (GLV), roots, tubers, fruits, mahua flowers, honey gum and many indigenous foods including tamarind and sell it to traders and government cooperatives for marginal income. Many studies revealed that indigenous plant foods have been cited as a potential source of essential micronutrients than conventional foods [13]. Epidemiological studies divulge that increased intake of GLV and vegetables are associated with decreased risk towards certain non-communicable diseases particularly cancers, cardiovascular disease, cataract, macular degeneration and other age-related ailments [14].

Indian tribal communities persist to remain the most nutritionally underprivileged social groups in the country and it is undeniable that their deprivation is influenced by a number of factors ranging from poverty and hunger due to loss of forest land and livelihood, poor re-habilitation actions, poor quality of essential food and nutrition services during critical periods of life, geographical remoteness. Recent survey reports have shown that more than half of tribal children under five years of age in India are stunted and wasted and fail to meet their potential for growth and development and this problem is extremely severe in Chenchu tribal children and is potentially the biggest threat to children growth and development. In addition of that the National Nutrition Monitoring Bureau, National Institute of Nutrition (NNMB-NIN) [15] reveals that tribal populations are at risk of under nutrition because of their dependence on primitive agricultural practices and uncertainty of food supply. Inaccessibility to health care facilities and ecological degradation further aggravate the situation. Stunted children are likely to fall ill, lack behind in education and could affect their performance and productivity [16]. From the last two decades, the precious edible and medicinal plants are wiped out owed to deforestation. Chenchu tribes are consuming 
rice provided by the government as a main course and due to poverty and lack of awareness on the balanced diet they are not consuming adequate nutritive food [17]. However, research suggests that the payback and significance of indigenous foods within India and the Asian context have not been fully understood and synthesized. Their potential value to the Indian food system could be improved if their benefits were explored more comprehensively.

The Chenchu tribes remain facing severe under nutrition and malnutrition problems in relevance to the other tribes in India. The reasons for higher prevalence of under nutrition may be due to poverty and consequent under nutrition, lack of awareness, access to and utilization of the available resources like GLV and forest related products which are high in nutrient content, social barriers which prevent their utilization of available nutrition supplementation program and services, poor environmental sanitation and lack of safe drinking water, leading to increased morbidity, which are associated with water-borne infections, favorable environmental conditions that promote vector-borne diseases and lack of access to health care facilities resulting in increased severity and /or duration of illnesses and death [16].

The wild plants are a main source of food and medicine for marginally surviving communities particularly for tribal people including Chenchu tribes. These plant foods possess rich nutrients and medicinal values. These wild plants provide health benefits as well as nutritive values. A functional food is one which not only serves to provide nutrition but also can be a source for prevention and cure of various diseases. In fact, these foods can be used as a good source of energy and nutrition to alleviate hunger and malnutrition in tribal population. Malnutrition continues to be a persistent public health problem and being well pronounced among the Scheduled Tribes. While the indicators of under nutrition among the Chenchu tribes in combined Andhra Pradesh are far behind the country's average figures and are much lower than the national averages of other tribal populations. A most important barrier is that people are not valuing indigenous foods and the potential advantage that can be resulting from using them is thus neglected. Furthermore, information is being misplaced from one generation to the next, with potentially dire implications for long-term sustainable food security. The study results show the need to identify and facilitate indigenous foods as a key resource in ensuring healthy food systems in the primitive tribes to meet the nutrition challenges. This effort presents about underutilized indigenous foods consumed by the primitive tribes Chenchu and their nutritional compilation.

\section{Materials and Methods}

\subsection{Capturing Data on Indigenous Foods}

Exploration of accessibility therapeutic use of indigenous foods in Nallamala forest region of selected Chenchu hamlets was covered during 2016-2019 using systematic random sampling procedure. In the initial phase of study, a campaign 
was launched in the chosen covered 34 villages and interacted with village elders, teachers, non-government organizations (NGOs), health works and local leaders. In each village focus group discussions, key informant's interviews, elder farmer's interviews were organized. This helped in listing and classifying various indigenous foods and their role in diets of the Chenchu community. Once list was completed supplementary issues were listed including seasonality, plant part utilized, preference and access. Each time of visit, different tribal hamlets and forest pockets were chosen in different seasons to collect more information. Such study was carried out by adopting the appropriate methodology [18]. Repeated interviews through questionnaires were made in different villages to authenticate the information and traditional/indigenous foods information was collected using pre tested open ended questionnaires. The indigenous foods consumed by Chenchu tribes were categorized depending on their edible portion. The information on types of food, availability, seasonality, frequency of consumption, parts being used and varieties were collected, the Chenchu elder person was taken as a key informant and used to identify with vernacular name and collect the sample. Digital camera was used for taking photographs during the field study. With the help of the institute of Trans disciplinary health sciences and technology (TDU) website [19] found the scientific names, family and therapeutic uses of the plants by using the vernacular names of the plants. All the collected indigenous plant foods were packed in a banana leaves and paper envelop covers and brought to the national institute of nutrition (NIN) within 48 hours. The nutritional composition of collected uncultivated plant foods was analyzed. The plants are enumerated alphabetically with their botanical name, family, local name, plant parts used and mode of uses (Table 1). The mode of use is given wherever recorded in the field.

\subsection{Sample Processing}

Green leafy vegetables, vegetables, roots, tubers and fruits are washed with portable water and wiped with tissue paper then air dried for few hours. The leafy vegetables are grinded with the mixer grinder. The outer layer of the roots and tubers were removed and grinded to fine powder. Seeds in the fruits were separated and the edible portion of the fruit was grinded all the samples were kept in oven at $55^{\circ} \mathrm{C}$ overnight to remove the moisture. Then the convinced number of samples were made to fine powder and stored in air tight containers for proximate analysis and the remaining sample were frozen in liquid nitrogen and lyophilized for 48 - 72 hours for vitamin analysis.

\subsection{Identification of Food Samples}

Existing on the free record movement done through Focus Group Discussion (FGD), a list of commonly consumed indigenous food ingredients was compiled (legumes, vegetables, leafy vegetables, seeds, fruits, and animal foods). Samples of identified substances were either provided by participants (if available) or were collected by the research team from deep forests with the help of local 
Table 1. List of indigenous medicinal plants in Chenchu habitations.

\begin{tabular}{|c|c|c|c|c|}
\hline Botanical name & Family & $\begin{array}{l}\text { Vernacular } \\
\text { Name }\end{array}$ & $\begin{array}{l}\text { Edible } \\
\text { portion }\end{array}$ & Therapeutic uses \\
\hline Acorus calamus & Acoraceae & Vasa & Root & Root powder used in epilepsy, dysentery and abnormal tumors \\
\hline Amaranthus tricolor & Amaranthaceae & Doggela kura & Leaf & $\begin{array}{l}\text { Decoction of the root is used with Cucurbita moschata to control } \\
\text { Hemorrhage, abortion }\end{array}$ \\
\hline Amaranthus viridis & Amaranthaceae & Chirraku & Leaf & Leaf extract mostly used for hypertension and digestion problems \\
\hline $\begin{array}{l}\text { Andrographis } \\
\text { paniculata }\end{array}$ & Acanthaceae & Nela vemu & Leaf & Leaf extract is used to treat malarial and typhoid fevers \\
\hline Aponogeton nataus & Aponogetonaceae & Kondi dumpa & Tuber & $\begin{array}{l}\text { Used in toothache, asthma, colic pain, and skin diseases and } \\
\text { as paste to control blood sugar }\end{array}$ \\
\hline Bambusa arundinacea & Poaceae & Veduru biyyam & Cereal & $\begin{array}{l}\text { Bamboo cooked rice is taken along with other dishes. Controls } \\
\text { back pain, joints pain, sugar, cholesterol and rheumatic pressure. }\end{array}$ \\
\hline Breynia retusa & Euphorbiaceae & Devadaru & Leaf & $\begin{array}{l}\text { Preparing curry with pulses with other ingredients \& fresh plant } \\
\text { juice are given as eye drop for eye infections and liver, } \\
\text { urinary and gastric ulcers disorders }\end{array}$ \\
\hline $\begin{array}{l}\text { Canthium } \\
\text { coromandelicum }\end{array}$ & Rubiaceae & Balusaaku & Leaf & $\begin{array}{l}\text { Leaves possess blood coagulation property useful in management of } \\
\text { minor injury and treatment of various ailments and skin diseases }\end{array}$ \\
\hline Capparis zeylanica $L$. & Capparaceae & Aadonda & Fruit & Rich in antioxidants to prevent cancers, diabetes and heart diseases \\
\hline Casearia elliptica & Flacourtiaceae & Chilakaduddiri & Leaf & $\begin{array}{l}\text { Leaf paste applied over the fractured areas. Stem bark crushed } \\
\text { and spread on wounds to heal }\end{array}$ \\
\hline Celosia argentea & Amaranthaceae & Gunugukura & Leaf & $\begin{array}{l}\text { Stems and leaves are bruised and applied as poultice, is used for } \\
\text { treating wounds and skin eruptions }\end{array}$ \\
\hline Cissampelos pareira & Menispermaceae & Bodhi kura & Leaf & $\begin{array}{l}\text { Used for the treatment of chronic non-healing ulcers, sinuses, } \\
\text { chronic skin diseases and in the treatment of poisonous bites }\end{array}$ \\
\hline Colocasia esculenta & Araceae & Chaam kura & Leaf & $\begin{array}{l}\text { Decoction of leaves is used to treat menstrual problem. } \\
\text { Inhibit human cancer cell growth }\end{array}$ \\
\hline Terminalia chebula & Combretaceae & Karakkaya & Fruit & Used for reduce temperature, cough, diarrhea, gastroenteritis \\
\hline Cordia dichotoma & Boraginaceae & Nakkera pandu & Fruit & $\begin{array}{l}\text { Leaves and stem bark are used for the treatment of dyspepsia, } \\
\text { fever, diarrhea, leprosy, gonorrhea and burning sensation }\end{array}$ \\
\hline Crataeva adansonii & Colchicaceae & Narlinga Pandu & Fruit & Leaves used in fumigations for treating jaundice, yellow fever \\
\hline Digera muricata & Amaranthaceae & Chenchala kura & Leaf & $\begin{array}{l}\text { Leaves are used in anaemia, asthma, internal inflammation of } \\
\text { intestine. In Ayurveda herb is considered as cooling, astringent to } \\
\text { the bowels and also used as laxative }\end{array}$ \\
\hline Dioscorea alata & Dioscoreaceae & Naarathega & Tuber & $\begin{array}{l}\text { Tuber paste is applied on cancerous wounds, leprosy, gonorrhoea, } \\
\text { blood pressure and in skin diseases. Tubers are boiled and cooked } \\
\text { with vegetables and mixed with rice }\end{array}$ \\
\hline Dioscorea bulbifera & Dioscoreaceae & Nalla gadda & Tuber & $\begin{array}{l}\text { Tubers boiled, removed outer layer and eaten Used to treat } \\
\text { diabetes, rheumatoid arthritis and parasitic worms }\end{array}$ \\
\hline Dioscorea hispida & Dioscoreaceae & Chanda gadda & Tuber & $\begin{array}{l}\text { Tuber paste is applied on affected parts to treat peeling feet. } \\
\text { After keeping the tubers overnight in water or after boiling, } \\
\text { it can be eaten as vegetable }\end{array}$ \\
\hline Dioscorea pentaphylla & Dioscoreaceae & Chenchugadda & Tuber & $\begin{array}{l}\text { Root paste mixed with milk for treating snake bites. } \\
\text { Tubers boiled with salt, mixed with rice and eaten as famine food }\end{array}$ \\
\hline Dioscorea wallichii & Dioscoreaceae & Nara dumpa & Tuber & Tuber extract is used to treat jaundice \\
\hline
\end{tabular}


Continued

\begin{tabular}{|c|c|c|c|c|}
\hline $\begin{array}{l}\text { Diospyros } \\
\text { melanoxylon }\end{array}$ & Ebenaceae & Tuniki pandu & Fruit & $\begin{array}{l}\text { Fruits are used to treat diarrhea, cholera, dysentery, cough, } \\
\text { pneumonia and tumors. Ripen fruit outer and inner layers are edible }\end{array}$ \\
\hline Gloriosa superba & Colchicaceae & Adavi naabhi & Tuber & Decoction of tubers used for gout and rheumatic-arthritis \\
\hline Grewia tiliaefolia & Tiliaceae & Jaana pandu & Fruit & $\begin{array}{l}\text { Outer layer of fruit precipitate used for treatment of asthma } \\
\text { and skin allergies }\end{array}$ \\
\hline Limonia acidissima & Rutaceae & Velagapandu & Fruit & $\begin{array}{l}\text { Pulp used to make syrups, drinks. It destroys intestinal worms } \\
\text { and cures chronic dysentery }\end{array}$ \\
\hline Madhuca longifolia & Sapotaceae & Vippa puvvu & Flower & $\begin{array}{l}\text { Oil extracted from the seeds is applied over the area effected with } \\
\text { skin diseases and body pain. Used for alcohol preparation purpose }\end{array}$ \\
\hline Nymphaea nouchali & Nymphaeaceae & Kaluva gadda & Seed & $\begin{array}{l}\text { Juice in combination with milk is used in Jaundice and anti-aging } \\
\text { \& aid in weight loss }\end{array}$ \\
\hline $\begin{array}{l}\text { Premna herbacea } \\
\quad \text { Roxb }\end{array}$ & Verbenaceae & Nelaneredu & Fruit & $\begin{array}{l}\text { Anti-oxidant, anti-microbial and anti-diabetic acid activity } \\
\text { and dysentery and respiratory disorder }\end{array}$ \\
\hline Vitex altissima & Lamiaceae & Nemali putha & $\begin{array}{c}\text { Leaf and } \\
\text { root }\end{array}$ & $\begin{array}{l}\text { Plant bark used as a poultice for treating Rheumatic swelling, } \\
\text { Acne, Allergies, and worm infestations }\end{array}$ \\
\hline Urginea nagarjunae & Liliaceae & Adavi ulligadda & Tuber & $\begin{array}{l}\text { The plant is used in Ayurveda for respiratory disorders, } \\
\text { skin diseases, dysmenorrhea, and intestinal worms }\end{array}$ \\
\hline Strychnos nux-vomica & Loganiaceae & Musti ginjalu & Seed & $\begin{array}{l}\text { The powdered seeds are employed in treatment of cold and } \\
\text { cough and atonics dyspentia }\end{array}$ \\
\hline Strychnos potatorum & Malvaceae & Chilla ginjalu & Seed & $\begin{array}{l}\text { Seeds powder with honey or the decoction of the seed is consumed } \\
\text { \& used for urine infection and seeds chewed for kidney problem }\end{array}$ \\
\hline Withania somnifera & Solanaceae & Aswa Gandha & Fruit & $\begin{array}{l}\text { Used in the treatment of poly arthritis, rheumatoid arthritis, } \\
\text { lumbago, asthma, leukoderma, general debility }\end{array}$ \\
\hline
\end{tabular}

Chenchu people. Identified exceptional plant foods from collected samples and analyzed for their nutritive values.

\subsection{Nutritional Analysis}

\subsubsection{Proximate Analyses}

All chemicals are analytical grade purchased from Sigma Aldrich (St. Louis, MO, USA) and other fine quality chemicals were acquired from Indian manufacturers. Proximate content of moisture, ash, and fat was determined using Association of Official Analytical Chemists [14]. Protein content $(M N \times 6.25)$ was estimated using AOAC Kjeldahl method [19] and total dietary fiber content was done by dietary fiber assay kit method (Sigma Aldrich) [15]. Carbohydrate analysis was calculated by difference [8].

\subsubsection{Mineral Analysis}

The closed vessel microwave digestion system (CEM-MARS-USA) was used to digest plant food samples (between 0.5 and $1.5 \mathrm{~g}$ ) and placed in a Teflon digestion vessel with $3 \mathrm{ml}$ of ultra-pure $\mathrm{HNO}_{3}$ and $1 \mathrm{ml}$ of Hydrogen Peroxide $\left(\mathrm{H}_{2} \mathrm{O}_{2}\right.$-Merck). Sealed containers were placed in a microwave oven and heated according to the digestion program (program: Power $1600 \mathrm{~W}$ (100\%), Ramp time 15 minutes, Temperature $2000^{\circ} \mathrm{C}$, Hold time 15 minutes and cooling time 
15 minutes). After digestion, sample solutions were cooled to room temperature and then transferred quantitatively in to acid cleaned $25 \mathrm{ml}$ standard volumetric flasks and made up to $25 \mathrm{ml}$ with double distilled deionized water and prepared under the same conditions as the calibration standards in $6 \%(\mathrm{v} / \mathrm{v}) \mathrm{HNO}_{3}$. A blank digest was carried out in the same way [14]. The concentrations of heavy and trace metal levels in indigenous foods were analyzed using Inductively Coupled Plasma Mass Spectroscopy (ICPMS). Rhodium (500 Ug/l) was used as the internal standard for all samples and multi-elemental standard (purchased from Sigma Aldrich) stock solution used for external calibration.

\subsubsection{Inductively Coupled Plasma Mass Spectroscopy (ICP-MS)}

Minerals were determined using ICP-MS (PerkinElmer Élan 9000-USA). For better operating conditions the ICP-MS was adjusted with Nebulizer gas flow $0.91 \mathrm{~L} / \mathrm{min}$, Radio frequency (RF) $1200 \mathrm{~W}$, Lens voltage $1.6 \mathrm{~V}$, Cool gas 13.0 $\mathrm{L} / \mathrm{min}$, and Auxiliary gas $0.70 \mathrm{~L} / \mathrm{min}$ [20]. Certified Reference Material (CRM) samples were procured from National Institute of Standard Technology (NIST) and European Union (EC) and used for method standardization and standard graphs were drawn. Recovery study was done.

Total carotenoids and water-soluble vitamins were analyzed using Ultra Performance Liquid Chromatography (UPLC) with standard protocols. Quantification and quality control were performed by external standard calibration using peak areas [21] [22] [23].

\section{Results and Discussion}

\subsection{Quality Control of the Analytical Method}

Method validation was performed with regard to accuracy, linearity and precision. The recovery and reproducibility were confirmed using SRM purchased from NIST and EU.

Enumeration: The medicinal plant species are enumerated alphabetically with their valid botanical name, family vernacular name(s), followed by availability status, parts used, ailments, dosage and mode of administrations.

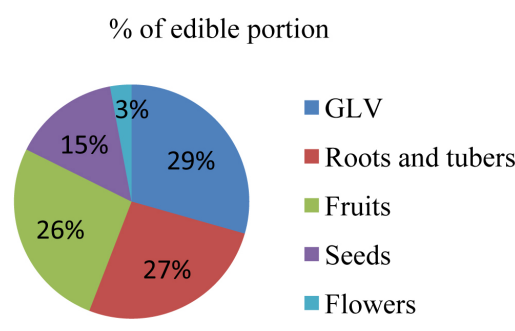

\begin{tabular}{cc}
\hline Plant part used & Number of plant foods \\
\hline GLV & 10 \\
Roots and tubers & 9 \\
Fruits & 9 \\
Seeds & 5 \\
Flowers & 1 \\
\hline
\end{tabular}

Apart from the medicinal uses most of the plant parts were found to be used in culinary preparation such as delicacy and some of them were used as food and spices. During the survey most of the people were approachable to share their knowledge because of their conservative believes. The preparation of medicine 
involves mixing of one or more ingredients extracted from various plant parts. India is one of the most biodiversity rich countries around the globe. The tribal communities living in the country are mainly dependent on the indigenous edible wild plant foods due to their availability. The present study made an attempt to document the medicinal uses, nutrition facts of the indigenous plants using the collected data. Total 34 indigenous plant foods belong to different families were collected and tabulated using convinced parameters like vernacular name, scientific name, family, edible portion, mode of consumption and therapeutic uses (Table 1). Among the 34 plants, 28 edible plants data was segregated on the basis of their parts consumed and it was found that the plant species give the wood are becoming extinct because of deforestation by the non-tribal people (other communities) and some species whose whole plant, roots, tubers, seeds and flowers are consumed are also in risk. Diascorea wallichi, Aponogeton natuns, Gloriosa superb are mentioned in the red data book. But mostly when Chenchus are collecting the roots or tubers, they leave some part of it in the ground, then the plant will grow again. In the given table, the number of species whose leaves are consumed as GLV is 9 , roots and tubers are 6 , fruits 9 , seeds 3 and flowers 1 in number.

\subsection{Proximate Analysis}

The proximate composition of indigenous foods on fresh weight basis results was shown in Table 2. The moisture content in analyzed food samples were ranges from 10.93 to 86.20 percentage and bamboo rice shown very less moisture due to dry weight basis. Ash content is very low in these food samples, usually in green leafy vegetables ash content is more. Ukam et al stated that the lower ash content represents usually the higher the nutrient quality [24]. The protein percentage representing in the analyzed foods ranges from 0.82 to 11.20 $\mathrm{mg} / 100 \mathrm{~g}$ found in Diospyros melanoxylon and the high value is found in Bambusa arundinacea. Many food samples consumed by the Chenchus are favorable levels of protein when compare with conventional foods. Proteins are helping the body for building repairing and maintaining tissues. Many hormones and enzymes that regulate body processes are made up of proteins. Proteins supply energy to the body in absence of carbohydrate and fat in diet. The fat content of the analyzed samples ranges from 0.02 to $1.92 \mathrm{mg} / 100 \mathrm{~g}$ found in Dioscorea hispida and Madhuca longifolia respectively. In the present food samples fat content shown very less values as compared to routinely consumed samples. Chenchus mostly consume roots and tubers which have very low-fat content and they show very thin and have very low body fat. The crude fiber levels were ranges from lower to higher are 0.73 to $4.67 \mathrm{~g} / 100 \mathrm{~g}$ in Dioscorea hispida and Canthium coromandelicu. Many studies possess that tubers have low fiber content when compare with fruits and flowers. Fiber cleanses the digestive tract by eradicating potential carcinogens from the body and binds cancer-binding chemicals keeping them away from the cells lining the colon [17]. Carbohydrates were calculated through by difference method. Carbohydrate ranges from 6.15 to $71.5 \mathrm{~g} / 100 \mathrm{~g}$ 
Table 2. Proximate composition of indigenous foods-(g/100g).

\begin{tabular}{|c|c|c|c|c|c|c|c|c|c|}
\hline \multirow{2}{*}{ Scientific name } & \multirow{2}{*}{ Moisture } & \multirow{2}{*}{ Ash } & \multirow{2}{*}{ Protein } & \multirow{2}{*}{ Fat } & \multicolumn{3}{|c|}{ Dietary fiber } & \multirow{2}{*}{$\begin{array}{l}\text { Carbo } \\
\text { hydrate }\end{array}$} & \multirow{2}{*}{$\begin{array}{c}\text { Energy } \\
\text { k. cal }\end{array}$} \\
\hline & & & & & Total & Insoluble & Soluble & & \\
\hline Bambusa arundinacea & $10.93 \pm 0.28$ & $1.31 \pm 0.06$ & $11.20 \pm 0.01$ & $0.52 \pm 0.07$ & $2.81 \pm$ & $1.99 \pm$ & $2+$ & $71.5 \pm 2.06$ & 344.8 \\
\hline Breynia retusa & $82.68 \pm 0.71$ & $1.09 \pm 0.06$ & $2.18 \pm 0.22$ & $0.45 \pm 0.01$ & $2.21 \pm 0.20$ & $1.64 \pm 0.05$ & $0.57 \pm 0.01$ & $12.01 \pm 0.51$ & 64.98 \\
\hline Canthium coromandelicu & $76.07 \pm 0.64$ & $1.50 \pm 0.04$ & $3.32 \pm 0.10$ & $0.81 \pm 0.06$ & $4.67 \pm 0.50$ & $3.06 \pm 0.02$ & $1.61 \pm 0.13$ & $13.63 \pm 0.42$ & 83.91 \\
\hline Celosia argentea & $82.04 \pm 1.12$ & $1.56 \pm 0.08$ & $6.84 \pm 0.53$ & $1.08 \pm 0.07$ & $2.63 \pm 0.47$ & $1.86 \pm 0.11$ & $0.78 \pm 0.02$ & $7.16 \pm 0.75$ & 70.70 \\
\hline Cissampelos pareira & $86.20 \pm 1.04$ & $1.42 \pm 0.12$ & $3.12 \pm 0.47$ & $0.35 \pm 0.03$ & $2.76 \pm 0.52$ & $1.81 \pm 0.23$ & $0.95 \pm 0.0$ & $6.15 \pm 0.81$ & 45.44 \\
\hline Colocasia esculenta & $79.00 \pm 2.38$ & $0.7 \pm 0.02$ & $0.95 \pm 0.01$ & $0.87 \pm 0.06$ & $1.16 \pm 0.14$ & $0.94 \pm 0.05$ & $0.22 \pm 0.01$ & $17.32 \pm 0.61$ & 83.10 \\
\hline Digera muricata & $81.49 \pm 3.44$ & $0.55 \pm 0.02$ & $1.60 \pm 0.07$ & $0.68 \pm 0.02$ & $3.29 \pm 0.62$ & $2.47 \pm 0.06$ & $0.82 \pm 0.12$ & $6.44 \pm 0.48$ & 152.05 \\
\hline Dioscorea pentaphylla & $69.35 \pm 0.72$ & $1.76 \pm 0.14$ & $2.07 \pm 0.15$ & $0.30 \pm 0.04$ & $1.58 \pm 0.62$ & $1.29 \pm 0.04$ & $0.29 \pm 0.03$ & $24.95 \pm 1.20$ & 113.7 \\
\hline Dioscorea bulbifera & $70.65 \pm 0.56$ & $1.92 \pm 0.09$ & $2.87 \pm 0.16$ & $0.35 \pm 0.07$ & $3.41 \pm 0.76$ & $3.08 \pm 0.09$ & $0.32 \pm 0.05$ & $18.94 \pm 0.88$ & 96.81 \\
\hline Dioscorea hispida & $66.92 \pm 0.81$ & $1.29 \pm 0.03$ & $2.38 \pm 0.21$ & $0.02 \pm 0.01$ & $0.73 \pm 0.18$ & $0.58 \pm 0.03$ & $0.15 \pm 0.01$ & $27.5 \pm 1.31$ & 121.07 \\
\hline Dioscorea wallichii & $76.50 \pm 2.85$ & $1.54 \pm 0.34$ & $2.52 \pm 0.18$ & $0.78 \pm 0.05$ & $1.75 \pm 0.21$ & $1.12 \pm 0.04$ & $0.63 \pm 0.01$ & $16.91 \pm 1.56$ & 90.16 \\
\hline Diospyros melanoxylon & $68.46 \pm 6.54$ & $3.87 \pm 0.24$ & $0.82 \pm 0.05$ & $0.64 \pm 0.03$ & $2.61 \pm 0.71$ & $2.04 \pm 0.02$ & $0.57 \pm 0.02$ & $22.64 \pm 1.08$ & 122.51 \\
\hline Limonia acidissima & $70.2 \pm 0.50$ & $3.47 \pm 0.13$ & $7.61 \pm 0.08$ & $1.72 \pm 0.14$ & $1.86 \pm 0.91$ & $1.24 \pm 0.07$ & $0.42 \pm 0.03$ & $10.85 \pm 0.48$ & 92.83 \\
\hline Madhuca longifolia & $70.83 \pm 0.29$ & $1.03 \pm 0.04$ & $3.27 \pm 0.03$ & $1.92 \pm 0.10$ & $3.57 \pm 0.84$ & $3.12 \pm 0.04$ & $0.45 \pm 0.04$ & $20.86 \pm 0.92$ & 114.42 \\
\hline Nymphaea nouchali & $55.23 \pm 0.43$ & $1.12 \pm 0.14$ & $1.24 \pm 0.04$ & $0.20 \pm 0.05$ & $4.61 \pm 0.95$ & $3.85 \pm 0.06$ & $0.76 \pm 0.04$ & $34.17 \pm 1.04$ & 152.15 \\
\hline
\end{tabular}

Cissampelos pareira and Bambusa arundinacea respectively. Followed by tuber, seeds and fruits are also having high amount of carbohydrate present which are frequently consumed by Chenchu tribes. Carbohydrates are main source of energy production in body. The calorific value of the analyzed samples was calculated using the Atwater factors of 4, 9, 1.89 and 4 for protein, fat, dietary fiber and carbohydrates respectively [19].

In rural population mainly tribal areas, traditional leafy vegetables play an important role as nutritional source, and it is accessible throughout the year. Green leafy vegetables are habitually considered as the cheapest source of food for vitamins and micronutrients supplementation to combat nutrients deficiencies. It is also used as herbal and medicinal plants in various cultural and traditional settings for many different ailments. There is an opportunity for research to recognize and discover the possibility of palatable leaves of indigenous and under-exploited plants for use as food and medicine and inclusion in mainstream agri-food systems. Research is also needed to explore different varieties and possibility of adopting agronomic practices that will reduce the concentration and effect of anti-nutritional factors in green leafy vegetables and enhance their nutritive value.

\subsection{Mineral's Analysis}

World Health Organisation (WHO-(1996) specified that the "overall malnutrition must no longer be considered without reference to micronutrient and min- 
eral status, as the two are inseparably connected? Attempting to evolution protein-energy status without addressing micronutrient deficiencies will not affect in ideal growth and function [25]. Metal ions are important to the normal functioning and wellbeing of humankind as they serve as cofactors in enzymatic reactions, and maintain protein structures.

The micronutrients in wild edible plants were significantly high. Results of mineral nutrients (Table 3 ) show remarkably high amounts of Sodium (Na) content $94.6 \mathrm{mg} / 100 \mathrm{~g}$ Dioscorea pentaphylla and lowest $2.32 \mathrm{mg} / 100 \mathrm{~g}$ was in Diospyros melanoxylon against to the Recommended Daily Allowance (RDA) for sodium is $500 \mathrm{mg}$ for adults. Sodium maintains fluid volume outside the cell thus normalize the cell functions. Magnesium $(\mathrm{Mg})$ content in analyzed tribal food's ranges from highest to lowest is 527.1 to $23.7 \mathrm{mg} / 100 \mathrm{~g}$ in Colocasia esculenta and Limonia acidissima and the RDA ranges from 310 - $420 \mathrm{mg}$. Magnesium is needed for more than 300 biochemical reactions in the body. It helps to maintain normal nerve and muscle function, supports a healthy immune system, keeps the heartbeat steady, and helps bones remain strong. It also helps adjust blood glucose levels. It aids in the production of energy and protein.

The main function of Phosphorus (P) is in the formation of bones and teeth. It plays an important role in how the body uses carbohydrates and fats. It is also needed for the body to make protein for the growth, maintenance, and repair of cells and tissues. The RDA of phosphorus is $1250 \mathrm{mg}$ for adults. The P levels in

Table 3. Mineral analysis in indigenous foods-mg/100g.

\begin{tabular}{|c|c|c|c|c|c|c|c|c|c|}
\hline Scientific name & $\mathrm{Na}$ & $\mathrm{Mg}$ & $\mathbf{P}$ & $\mathbf{K}$ & $\mathrm{Ca}$ & Mn & $\mathrm{Fe}$ & $\mathrm{Cu}$ & $\mathrm{Zn}$ \\
\hline Bambusa arundinacea & $4.11 \pm 0.06$ & $89.5 \pm 8.56$ & $208 \pm 36.7$ & $212 \pm 12.9$ & 25.3 & & 1.43 & 0.03 & 0.27 \\
\hline Breynia retusa & $12.68 \pm 2.08$ & $76 \pm 5$ & 0.00 & $8 \pm 4$ & $207 \pm 2$ & & $16.5 \pm 1.52$ & $0.71 \pm 0.01$ & $6.25 \pm 0.85$ \\
\hline $\begin{array}{c}\text { Canthium } \\
\text { coromandelicum }\end{array}$ & $41.72 \pm 1.62$ & $176 \pm 2.86$ & $25.6 \pm 2.53$ & $376 \pm 20.5$ & $339 \pm 18.35$ & $1.35 \pm 0.41$ & $9.13 \pm 1.03$ & $0.25=$ & 0.00 \\
\hline Celosia argentea & $62.99 \pm 5.08$ & $167 \pm 6.48$ & $35.3 \pm 2.85$ & $526 \pm 3.62$ & $28 \pm 5.24$ & $1.86 \pm 0.06$ & $31.8 \pm 1.28$ & $2.06 \pm 0.69$ & $4.45 \pm 0.61$ \\
\hline Cissampelos pareira & $15.47 \pm 2.04$ & $156.82 \pm 12.8$ & $29.67 \pm 3.4$ & $386 \pm 14$ & $272 \pm 18$ & & $8.44 \pm$ & $0.51 \pm$ & $0.95 \pm 0.01$ \\
\hline Colocasia & $25.9 \pm 0$ & $527.1 \pm 62.4$ & $42.5 \pm 2.68$ & $532 \pm$ & $734.2 \pm 4.26$ & $1.98 \pm 0.04$ & $0.92 \pm$ & $0.62 \pm 0.13$ & $1.25 \pm 0.66$ \\
\hline Digera muricata & $7.58 \pm 1.26$ & $264 \pm 10.56$ & $48.2 \pm 5.44$ & $763 \pm 6.87$ & $493 \pm 25.11$ & $0.31 \pm 0.01$ & $14.6 \pm 2.92$ & $0.26 \pm 0.05$ & $0.62 \pm 0.11$ \\
\hline Dioscorea bulbifera & $72.5 \pm 2.13$ & $370.6 \pm 8.65$ & $128 \pm 33.43$ & $1567 \pm 20.6$ & $347 \pm 38.06$ & $6.13 \pm 0.41$ & $17.86 \pm 1.03$ & $0.92 \pm 0.06$ & $1.89 \pm 0.50$ \\
\hline Diascorea hispida & $58.24 \pm 5.62$ & $324.15 \pm 21.5$ & $102.8 \pm 15.7$ & $1126 \pm 26$ & $209 \pm 17.1$ & $3.06 \pm 0.43$ & $13.79 \pm 1.53$ & $2.22 \pm 0.36$ & $1.95 \pm 0.04$ \\
\hline Dioscorea pentaphylla & $94.6 \pm 2.46$ & $452.4 \pm 21.23$ & $118 \pm 33.19$ & $1320 \pm 54.0$ & $419.1 \pm 3.58$ & $2.39 \pm 0.02$ & $4.26 \pm 0.08$ & $8.71 \pm 0.22$ & $2.41 \pm 0.05$ \\
\hline Dioscorea wallichii & $58.4 \pm 0.84$ & $531.6 \pm 2.08$ & $105 \pm 18.61$ & $1021 \pm 57.6$ & $735.1 \pm 12.42$ & $3.40 \pm 0.01$ & $21.12 \pm 0.62$ & $2.07 \pm 0.36$ & $6.21 \pm 0.21$ \\
\hline Diospyros melanoxylon & $2.32 \pm 0.64$ & $38.1 \pm 3.55$ & $62.2 \pm 8.69$ & $384 \pm 53.5$ & $193 \pm 24.25$ & $0.73 \pm 0.02$ & $0.94 \pm 0.15$ & $0.02 \pm 0.00$ & $0.41 \pm 0.02$ \\
\hline Limonia acidissima & $2.42 \pm 0.08$ & $23.7 \pm 1.05$ & $127 \pm 7.52$ & $358 \pm 14.3$ & $82.8 \pm 13.22$ & $0.36 \pm 0.01$ & $1.76 \pm 0.67$ & $0.28 \pm 0.01$ & $1.48 \pm 0.02$ \\
\hline Madhuca longifolia & $6.12 \pm 0.72$ & $173.5 \pm 15.4$ & $218.7 \pm 10.6$ & $279 \pm 31.8$ & $756 \pm 48.66$ & $2.14 \pm 0.04$ & $15.34 \pm 0.33$ & $0.23 \pm 0.08$ & $0.84 \pm 0.06$ \\
\hline Nymphaea nouchali & $10.25 \pm 1.75$ & $10.5 \pm 0.86$ & $21.4 \pm 11.24$ & $215 \pm 26.16$ & $159 \pm 16.17$ & $1.94 \pm 0.06$ & $14.78 \pm 3.86$ & $0.69 \pm 0.10$ & $7.56 \pm 1.48$ \\
\hline
\end{tabular}

Na: Sodium, Mg: Magnesium, P: Phosphorus, K: Potassium, Ca: Calcium, Mn: Manganese, Fe: Iron, Cu: Copper, Zn: Zinc. 
the present study shown from 218 to $21.4 \mathrm{mg} / 100 \mathrm{~g}$ in Madhuca longifolia and Nymphaea nouchali. Potassium (K) contented ranges from 1567 - $58 \mathrm{mg} / 100 \mathrm{~g}$ in Dioscorea bulbifera and Breynia retusa It is an important mineral that functions as an electrolyte. It helps to regulate fluid balance, nerve signals and muscle contractions. The RDA for potassium is $2500 \mathrm{mg}$ for adults. The body needs Calcium $(\mathrm{Ca})$ to maintain strong bones and to carry out many important functions. In addition, calcium is used to help blood vessels move blood throughout the body and to help release hormones and enzymes that affect almost every function in the human body. In the present study Ca levels shown range from highest to lowest is 756 - $25.3 \mathrm{mg} / 100 \mathrm{~g}$ in Madhuca longifolia and Bambusa arundinacea. RDA of calcium is $1200 \mathrm{mg}$ per day. Manganese (Mn) is an essential element that can be found ubiquitously in the air, soil, and water, most of which is found in the liver, bones, and kidneys in human. This trace element is a cofactor for a number of important enzymes, including arginase, cholinesterase, phosphoglucomutase, pyruvate carboxylase, mitochondrial superoxide dismutase, and several phosphates, peptidases, and glycosyltransferases. In certain instances, $\mathrm{Mn}^{2+}$ may be replaced by $\mathrm{Co}^{2+}$ or $\mathrm{Mg}^{2+}$. It helps for the formation of prothrombin with vitamin $\mathrm{K}$. Mn levels shown range from highest to lowest is $6.14-0.31 \mathrm{mg} / 100 \mathrm{~g}$ in Breynia retusa and Digera muricata. Iron $(\mathrm{Fe})$ is one of the most important minerals in living organisms. The content of $\mathrm{Fe}$ is ranges from 31.8 - $0.92 \mathrm{mg} / 100 \mathrm{~g}$ in Celosia argentea and Colocasia esculenta respectively. Anemia is one of the severe problems in women and adolescent girls particularly in tribal population. Iron involves in many biological functions including transportation of hemoglobin along with transferrin protein. Iron content is very high in the present samples when compared to commercially consumed GLVs. Iron is required for hemoglobin formation and its deficiency leads to anemia. Copper $(\mathrm{Cu})$ in the blood exists in two forms and bound to ceruloplas$\min (85 \%-95 \%)$, and the rest "free," loosely bound to albumin and small molecules. Free $\mathrm{Cu}$ causes toxicity, as it generates reactive oxygen species such as superoxide, hydrogen peroxide, and the hydroxyl radical. These damage proteins, lipids, and DNA. The copper levels were found to ranges from 8.71 to $0.02-\mathrm{mg} / 100 \mathrm{~g}$ in Dioscorea pentaphylla and Diospyros melanoxylon. It is found in all body tissues and plays a role in making red blood cells and maintaining nerve cells and the immune system. It also helps the body form collagen and absorbs iron and plays a role in energy production. Zinc $(\mathrm{Zn})$ levels in the present study ranges from 6.25 - $0.27 \mathrm{mg} / 100 \mathrm{~g}$ in Breynia retusa and Bambusa arundinacea. Zinc is needed for the body's defensive (immune) system to properly work. It plays a role in cell division, cell growth, wound healing, and the breakdown of carbohydrates. The use of wild edible leaves in our diet could help boasting in blood level especially in anaemic conditions.

\subsection{Vitamin Analysis}

Vitamin analysis was shown in Table 4. Vitamins are extensive a group of organic compounds that are essential for normal body function. There is increased 
Table 4. Vitamins analysis in indigenous foods-mg/100g.

\begin{tabular}{ccccccc}
\hline Scientific name & Riboflavin & Niacin & Pantothenic acid & Pyridoxine & Ascorbic acid & Total Carotenoids \\
\hline Bambusa arundinacea & $0.036 \pm 0.01$ & $1.84 \pm 0.02$ & 0.00 & $0.124 \pm 0.08$ & 0.00 & $13.1 \pm 2.06$ \\
Breynia retusa & $0.062 \pm 0.01$ & $0.07 \pm 0.01$ & $0.062 \pm 0.03$ & $0.105 \pm 0.04$ & $10.04 \pm 2.75$ & $9.86 \pm 1.40$ \\
Canthium coromandelicum & $0.261 \pm 0.03$ & $0.48 \pm 0.01$ & $0.055 \pm 0.009$ & $0.092 \pm 0.01$ & $18.65 \pm 4.52$ & $15.5 \pm 1.05$ \\
Celosia argentea & $0.112 \pm 0.04$ & $0.61 \pm 0.01$ & $0.026 \pm 0.007$ & $0.126 \pm 0.05$ & $48.06 \pm 11.02$ & $36.1 \pm 3.14$ \\
Cissampelos pareira & $0.013 \pm 0.002$ & $0.24 \pm 0.01$ & $0.011 \pm 0.001$ & $0.045 \pm 0.003$ & $12.43 \pm 0.02$ & $8.62 \pm 0.47$ \\
Colocasia esculenta & $0.047 \pm 0.01$ & $0.51 \pm 0.01$ & $0.212 \pm 0.04$ & $0.341 \pm 0.08$ & $3.82 \pm 1.00$ & $1.27 \pm 0.02$ \\
Digera muricata & $0.087 \pm 0.01$ & $0.37 \pm 0.03$ & $0.194 \pm 0.05$ & $0.137 \pm 0.09$ & $42.14 \pm 7.16$ & $17.3 \pm 0.65$ \\
Dioscorea bulbifera & $0.082 \pm 0.05$ & $0.51 \pm 0.62$ & $0.284 \pm 0.02$ & $0.128 \pm 0.07$ & $24.45 \pm 0.81$ & $1.09 \pm 0.03$ \\
Diascorea hispida & $0.028 \pm 0.01$ & $0.38 \pm 0.54$ & $0.0192 \pm 0.00$ & $0.240 \pm 0.02$ & $20.50 \pm 0.14$ & $1.02 \pm 0.21$ \\
Dioscorea pentaphylla & $0.042 \pm 0.01$ & $0.86 \pm 1.08$ & $0.354 \pm 0.10$ & $0.236 \pm 0.02$ & $25.93 \pm 0.52$ & $1.18 \pm 0.05$ \\
Dioscorea wallichi & $0.051 \pm 0.006$ & $0.34 \pm 0.69$ & $0.197 \pm 0.06$ & $0.113 \pm 0.06$ & $18.40 \pm 2.06$ & $1.04 \pm 0.07$ \\
Diospyros melanoxylon & $0.124 \pm 0.04$ & $0.20 \pm 0.02$ & $0.185 \pm 0.08$ & 0.00 & $12.73 \pm 3.07$ & $1.76 \pm 0.23$ \\
Limonia acidissima & $0.024 \pm 0.01$ & $0.92 \pm 0.01$ & $0.214 \pm 0.05$ & $0.024 \pm 0.01$ & $17.55 \pm 2.69$ & $0.42 \pm 0.05$ \\
Madhuca longifolia & $0.41 \pm 0.09$ & $4.2 \pm 0.81$ & 0.00 & $0.072 \pm 0.03$ & $40 \pm 12.05$ & $0.38 \pm 0.08$ \\
$\begin{array}{c}\text { Nymphaea nouchali } \\
\text { Nym }\end{array}$ & $0.014 \pm 0.003$ & $0.43 \pm 0.03$ & 0.00 & 0.00 & $8.24 \pm 1.74$ & $1.30 \pm 0.10$ \\
\hline & & & & &
\end{tabular}

interest in nutritionally rich foods that are either normal or marginally processed. The use of emerging technologies intended at enlightening the constancy and bio accessibility of vitamins in foods to maintain their functionality over their bioavailability, metabolism, and health-promoting activity has also increased. water-soluble vitamins travel freely through the body, and excess amounts usually are excreted by the kidneys. The body needs water-soluble vitamins in frequent, insignificant doses. These vitamins are not as likely as fat-soluble vitamins to reach toxic levels. But niacin, vitamin B6, folate, choline, and vitamin $\mathrm{C}$ have upper consumption limits. Vitamin B6 at high levels over a long period of time has been shown to cause irreversible nerve damage. Vitamins were analyzed from the indigenous foods consumed by Chenchu tribes and the ranges of vitamins were shown marginally higher values than the commonly consumed foods. The vitamins include, total carotenoids and water-soluble vitamins particularly vitamin C, Riboflavin, Niacin, Pantothenic acid and Pyridoxine were analyzed. Vitamin B2 (Riboflavin) values were ranges from highest to lowest 0.26 to $0.024 \mathrm{mg} / 100 \mathrm{~g}$ in Canthium Coromandelicum and Limonia acidissima respectively followed by vitamin B3 (Niacin) highest value 4.2 $\mathrm{mg} / 100 \mathrm{~g}$ were found in Madhuca longifolia and lower range $0.07 \mathrm{mg} / 100 \mathrm{~g}$ was estimated in Breynia retusa. Vitamin B5 (Pantothenic acid) values are vary among the indigenous food samples. They found from highest to lowest ranges from 0.357 to $0.026 \mathrm{mg} / 100 \mathrm{~g}$ in Dioscorea pentaphylla and Celosia argentea. The other important vitamin B6 (Pyridoxine) promoting many biological functions as cofactor in metabolism. The values were ranges from 0.341 to $0.024 \mathrm{mg} / 100 \mathrm{~g}$ 
in Colocasia esculenta and Limonia acidissima. Vitamin C (Ascorbic acid) is an antioxidant and part of an enzyme needed for protein metabolism, important for immune system health, aids in iron absorption. It is found from 48.06 to 2.93 $\mathrm{mg} / 100 \mathrm{~g}$ in Celosia argentea and Dioscorea pentaphylla respectively. Total carotenoids are predominant in all green leafy vegetables and they needed for vision, healthy skin and mucous membranes, bone and tooth growth, immune system health. The levels of Total carotenoids were from 36.04 to $1.04 \mathrm{mg} / 100 \mathrm{~g}$ in Celosia argentea Dioscorea wallichi respectively.

The results of our study showed a strong favorite for micronutrient-dense indigenous GLVs as part of the daily diet. Every day's consumption of local foods is very important for the food and nutrition security of people living in traditional societies and rural areas. But the indigenous tribal population was not aware of the manifold ways of utilizing these for regular consumption as well as methods of preservation for use during the seasons of the year when they are not available. In addition, these foods can demonstrate to be an important approach to harmonize the routine micro nutrients for improving health, maternal and child micronutrient status in these communities. The neglected and underutilized food resources that are present in indigenous food environments constitute the foundation of the diversity in traditional and indigenous food systems of developing country communities and would be important in addressing challenges specific to indigenous groups. This exists amidst a rich knowledge of traditional foods that have potential to contribute to micronutrient intake. Knowledge of the edibility of a wide variety of indigenous flora and fauna exists in the community. What is perhaps missing is the value associated with these foods in terms of their nutritional quality, which could be leading to suboptimal intakes. Thus, there is a need to create awareness about the nutritional quality of these indigenous foods and effectively package the message with promotion of indigenous foods through nutrition education and advocacy. Thus, continuous and sustainable use of indigenous and wild foods can be a cost-effective strategy to address nutritional security and lead to sustainable ecosystem health and nutrition for the Chenchu tribal community of Andhra Pradesh and Telangana.

\section{Limitations}

The study was an investigative effort where till now undocumented indigenous foods in the Chenchu tribal community were listed and analyzed. Though, due to logistic reasons including difficult terrain and sample transport, only an inadequate number of food items could be analyzed. We consider that there is enormous scope for building on this study to enlarge and merge the accessible account of aboriginal foods in the study population. The researchers accepted the information provided about the standard procedures and methodology adopted by the laboratory.

\section{Conclusion}

Indigenous Peoples, exclusively women and children, are affected disproportio- 
nately by malnutrition and diet related health problems. Addressing this problem requires an investigation of the structural conditions that underlie unequal access to resources and loss of traditional lifestyles and necessitates inclusive approaches that shed light on these issues and provide strategies to leverage change. The aboriginal foods acknowledged in the study were originated to be rich sources of essential micronutrients. These foods are adapted to the local agro-ecosystem and do not need any particular inputs for their crop growing and sustainability. Promoting the consumption of indigenous foods by creating an enabling environment for increasing awareness of their nutritional benefits could make a substantial impact on the Chenchu community's nutrition security and nutritional status. Transferring knowledge of these indigenous foods along with their nutritive values to future generations would also facilitate their persistent use. The present study may thus lay concrete on the path toward further investigations into quantitative consumption estimates of these foods by the community. To the best of our understanding, no earlier study has looked at the nutritional aspects of the indigenous foods in the tribes of Chenchu in an incorporated approach. Data on these aspects could be a warehouse of information for botanists, agriculturists and nutritional experts alike and form a precious source for researchers and for the community to build upon and preserve. Local governments and policy makers also need to focus on this unmapped area and encourage research studies to identify more indigenous foods and promote intake and their prospective for alleviating widespread nutritional and dietary deficiencies. Policies addressing priorities will be needed to overcome these challenges and developing a system that promotes optimal health, environmental and economic sustainability and appeals to consumer choice will require an integrated framework. Progress has been made over the decades in improving food security, nutrition, health and income. Further progress will require concerted efforts to ensure that food security and nutrition continue to be a priority in the development agenda.

\section{Acknowledgements}

Authors thank tribal welfare commissioner, Government of Telangana state for their funding support and encouragement. Also, thanks for local herbal practitioners for providing information and for their assistance during the fieldwork.

\section{Conflicts of Interest}

The authors declare no conflicts of interest regarding the publication of this paper.

\section{References}

[1] Hill, K., Barker, B. and Vos, T. (2007) Excess Indigenous Mortality: Are Indigenous Australians More Severely Disadvantaged than Other Indigenous Populations? International Journal of Epidemiology, 36, 580-589.

https://doi.org/10.1093/ije/dym011 
[2] Lee, A.J., Leonard, D., Moloney, A.A. and Minniecon, D.L. (2009) Improving Aboriginal and Torres Strait Islander Nutrition and Health. Medical Journal of Aus tralia, 190, 547-548. https://doi.org/10.5694/j.1326-5377.2009.tb02559.x

[3] Anderson, I., Crengle, S., Leialoha Kamaka, M., Chen, T.H., Palafox, N. and Jackson-Pulver, L. (2006) Indigenous Health in Australia, New Zealand, and the Pacific. The Lancet, 367, 1775-1785. https://doi.org/10.1016/S0140-6736(06)68773-4

[4] Australian Bureau of Statistics, Australian Institute of Health and Welfare (2008) The Health and Welfare of Australia's Aboriginal and Torres Strait Islander Peoples 2008. Canberra (Australia).

[5] Cochrane, S. (2008) Community Focus Groups on Food and Physical Activity Availability and Issues in Rural NSW Communities: Many Rivers Diabetes Prevention Project. CRIAH Aboriginal Health Conference, Sydney.

[6] National Aboriginal and Torres Strait Islander Social Survey. http://abs.gov.au/AUSSTATS/abs@.nsf/mf/4714.0

[7] Drewnowski, A. (2009) Obesity, Diets, and Social Inequalities. Nutrition Reviews, 67, S36-S39. https://doi.org/10.1111/j.1753-4887.2009.00157.x

[8] Ruben, A.R. (2009) Undernutrition and Obesity in Indigenous Children: Epidemiology, Prevention, and Treatment. Pediatric Clinics of North America, 56, 1285-1302. https://doi.org/10.1016/j.pcl.2009.09.008

[9] Rajpramukh, K.E. (2012) Tribal Health in Eastern Ghat. Concept Publication Company, New Delhi, 28.

[10] Registrar General of India (2011) Census. Office of the Registrar General and Census Commission, New Delhi, Ministry of Home Affairs, Government of India, New Delhi.

[11] Government of India (1982) The Constitution (Scheduled Tribes) Order 19.

[12] Government of India (1985 \& 1990) The Constitution (Scheduled Tribes) Order.

[13] Duguma, H.T. (2020) Wild Edible Plant Nutritional Contribution and Consumer Perception in Ethiopia. International Journal of Food Science, 2020, Article ID: 2958623. https://doi.org/10.1155/2020/2958623

[14] Thurnham, D.I. (2007) Bioequivalence of Beta Carotene and Retinol. Journal of Science of Food and Agriculture, 87, 13-39. https://doi.org/10.1002/jsfa.2647

[15] NIN (2009) National Nutrition Monitoring Bureau (NNMB), Diet and Nutritional Status of Tribal Population and Prevalence of Hypertension among Adults-Report as Second Repeat Survey. NNMB Technical Report No. 25, National Institute of Nutrition, Hyderabad.

[16] Sreenivasa Rao, J., Shivudu, G., Panda, H. and Kalyan Reddy, P. (2019) Livelihood Strategies Resource and Nutritional Status of Forest Dependent Primitive Tribes Chenchu in Andhra Pradesh and Telangana States. Nutrition and Food Science International Journal, 8, Article ID: 555735.

[17] Tribal Health in Eastern Ghat. Concept Publication Company, New Delhi, 28.

[18] Jain, S.K. (1989) Methods and Approaches in Ethnobotany. National Botanical Research Institute, Lucknow.

[19] Institute of Trans-Disciplinary Health Sciences and Technology (2019). http://envis.frlht.org/vernacular search.php

[20] Noel, L., Dufailly, V., Lemahieu, N., Vastel, C. and Guerin, T. (2005) Simultaneous Analysis of Cadmium, Lead, Mercury, and Arsenic Content in Foodstuffs of Animal Origin by Inductively Coupled Plasma/Mass Spectrometry after Closed Vessel Microwave Digestion, Method Validation. Journal of AOAC International, 88, 1811-1821. 
https://doi.org/10.1093/jaoac/88.6.1811

[21] Nelis, H.J.C.F. and De Leenheer, A.P (1983) Isocratic Nonaqueous Reversed-Phase Liquid Chromatography of Carotenoids. Analytical Chemistry, 55, 270-275. https://doi.org/10.1021/ac00253a021

[22] Marx, M., Stuparic, M., Schieber, A. and Carle, R. (2003) Effects of Thermal Processing on Trans-Cisisomerization of b-Carotene in Carrot Juices and Carotene-Containing Preparations. Food Chemistry, 83, 609-617. https://doi.org/10.1016/S0308-8146(03)00255-3

[23] Delia, B., Rodriguez-Amaya and Kimura, M. (2004) HarvestPlus Handbook for Carotenoid Analysis. HarvestPlus.

[24] Ukam, N.U., Mgbekem, M., Edide, R. and Obizoba, I.C. (2016) Nutrient and Phytochemical Composition of Five Wild Green Leafy Vegetables Consumed in Erie-Biase Local Government Area of Cross River State. Food and Nutrition Sciences, 7, 817-823. https://doi.org/10.4236/fns.2016.79082

[25] Baudoin, W.O. and Louise Fresco, O. (2002) Food and Nutrition Security towards Human Security. ICV Souvenir Paper, 1-19. 